\title{
Development of Productivity-based Estimating Tool for Fuel Use and Emissions from Earthwork Construction Activities
}

\author{
Apif M. Hajji ${ }^{1}$ and Michael Phil Lewis ${ }^{2}$
}

\begin{abstract}
Earthwork activities are typically performed by heavy duty diesel (HDD) construction equipment that consumes large quantities of diesel fuel use and emits large quantities of pollutants, including nitrogen oxides (NOx), particulate matters $(\mathrm{PM})$, hydrocarbon $(\mathrm{HC})$, carbon monoxide $(\mathrm{CO})$, and carbon dioxide $\left(\mathrm{CO}_{2}\right)$. This paper presents the framework for a model that can be used to estimate the production rate, activity duration, total fuel use, and total pollutants emissions for earthwork activities. A case study and sensitivity analysis for an excavator performing excavations are presented. The tool is developed by combining the multiple linear regressions (MLR) approach for modeling the productivity with the EPA's NONROAD model. The excavator data from RSMeans Heavy Construction Data were selected to build the productivity model, and emission factors of all type of pollutants from NONROAD model were used to estimate the total fuel use and emissions. The MLR model for the productivity rate can explain $92 \%$ of the variability in the data. Based on the model, the fuel use and emissions of excavator increase as the trench depth increase, but as the bucket size increase, the fuel use and emissions decrease.
\end{abstract}

Keywords: productivity, fuel use, emissions, construction equipment

\section{INTRODUCTION}

Earthwork activities are an important part of most construction projects. Oftentimes, these activities account for the majority of the total cost of the project compared to other tasks. Furthermore, these activities are typically completed by heavy duty diesel (HDD) construction equipment that consume large quantities of diesel fuel and thus emit large quantities of pollutants, including nitrogen oxides (NOx), particulate matters (PM), hydrocarbon (HC), carbon monoxide $(\mathrm{CO})$, and carbon dioxide $\left(\mathrm{CO}_{2}\right)$ or greenhouse gas (GHG) emission. The energy and environmental impact of earthwork activities is significant.

Construction estimators have long been able to estimate the costs associated with HDD and the earthwork activities that they perform. Likewise, they have typically been able to approximate the amount of fuel that would be required. Moreover, most construction estimators seldom concerned themselves with the environmental impact, specifically air pollutant emissions, of the equipment that they used.

As new environmental regulations appear on the horizon in other industries, construction professionals can no longer afford to disregard the environmental aspects of their work. They need a tool that can be used with their existing expertise to quantify the energy and environmental impact of earthwork activities. The objective of this paper is to propose an innovative approach for estimating the fuel use and emissions from HDD equipment performing earthwork construction activities.

\section{RELATED WORKS}

Some methods have been studied to measure emissions from HDD equipment. Some emission measurement methods are used to measure emission from in-use HDD equipment by using an on-board instrument attached to the engine. Some studies tried to simulate or make models to estimate the emissions. The government or state agencies like EPA or California Air Resource Board (CARB) also develop models to estimate emissions from construction equipment.

Real-World In-Use measurement is the methodology for collecting real world air pollutant emissions from in-use HDD equipment. The methodology consists of second-bysecond measurement of working equipment using Portable Emissions Measurement System (PEMS) [1-3]. The results of emissions measurement from PEMS can be used to develop real-world emissions inventories of various types of HDD vehicles. Lewis, Frey, \& Rasdorf [4] presented a new methodology for developing an emission inventory for construction vehicles on the basis of real world data. The

${ }^{1}$ Assistant Professor, Civil Engineering Department, Universitas Negeri Malang, Indonesia - apif.hajji@ okstate.edu (*Corresponding Author)

${ }^{2}$ Assistant Professor, School of Civil and Environmental Engineering, Oklahoma State University, Stillwater OK, USA 
results of PEMS can also be used for comparing different emission characteristics from different types of diesel fuel. Frey \& Kim [5] used PEMS procedure to study the characteristics of real-world fuel use and in-use on-road emissions from dump trucks using B20 biodiesel and petroleum diesel.

An emission estimation tool can also be developed by using models or simulations. This method does not require a specific instrument to be attached on HDD equipment. Some studies used engine parameters, or fuel characteristics, or type of equipment's activities to estimate or predict the emissions rates. That is a DiscreteEvent Simulation (DES), which can be used as an approach to estimate emissions [6]. DES can simulate a project or operation by running chronological occurred events. By calculating durations of work package, DES will estimate the emissions [7]. Li \& Lei [8] studied the use of Discrete-Event Simulation (DES) in estimating and analysing $\mathrm{CO}_{2}$ emission during earthwork construction. Ammouri et al. [9] proposed a model capable of estimating the total carbon footprint of a construction project taking into consideration the size, landscape, and material of construction. The proposed model, which is called as Carbon Footprint Calculator for Construction Project (CFCCP), utilized the detailed project bill of quantity and schedule timeline to produce a precise calculation of the total footprint. Thompson et al. [10] used the Artificial Neural Network (ANN) model to predict relationship between the output torques and exhaust emissions from heavy duty diesel engine with limited use of dynamometer testing. The result showed that the ANN was able to predict the instantaneous emissions of $\mathrm{HC}, \mathrm{CO}, \mathrm{CO}_{2}, \mathrm{NO}_{\mathrm{x}}$, and $\mathrm{PM}$ and opacity for a HDD engine. In concern with fuel properties, Karonis, et al. [11] used ANN to model the exhaust emissions from a single-cylinder diesel engine with some of the most important properties of fuels. Air pollutants and GHG emissions are direct by-product of fuel consumption and fuel consumption is dependent upon equipment productivity. Because productivity is simply defined as the ratio between the work quantity and the duration, it reveals that the duration is inversely proportional to productivity. When the productivity decreases, the duration will increase and results in higher cost, higher fuel consumption, and higher emissions. Although there are existing models that estimate and measure emissions inventories of HDD equipment, these approaches generally only focus on environmental issues, not the productivity or other earthwork activity attributes. The objective of this paper is to propose a tool for estimating the fuel use and emissions footprint based on the productivity of HDD equipment.

\section{METHODOLOGY}

This proposed estimating tool is developed by combining the productivity rate model from a reliable construction estimating data sources and the calculation algorithm employed by the Environmental Protection Agency (EPA) NONROAD model (Figure 1). In order to develop the productivity rate model for HDD, a simple earthwork activity performed by excavator was selected. The data for this activity was collected from RSMeans Heavy Construction Data 2011, Division 31: Earthwork, Sub-division 31.23: Excavation and Fill, Section 31.23.23: Fill, and Sub-section 31.23.16.13: Excavating Trench. RSMeans data is the most powerful and widely accepted construction tool available to construct an estimate and as reference for current construction productivity and cost for any type of project. This item provides 195 total observations of excavator activities based on bucket capacity in loose cubic yard (0.5-3.5 lcy), depth of trench (6-24 feet), four soil types (sand-gravel, sandy clay-loam, common earth, and clay), and three excavator types (excavator, excavator-truck mounted, excavator-trench box).

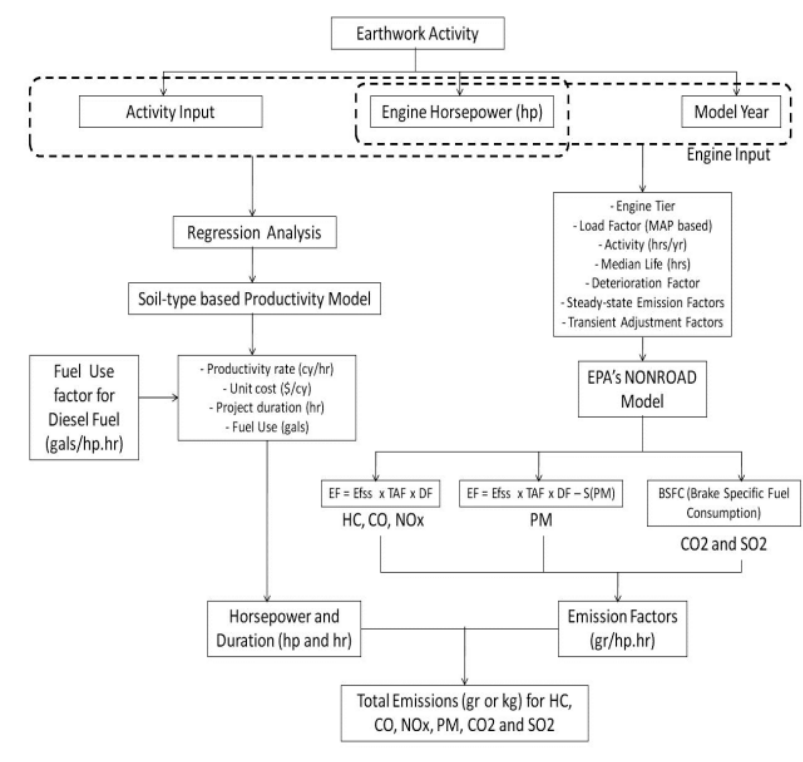

FIGURE I

Research Methodology Flowchart For Estimating Fuel Use and EMISSIONS

Based on the data from RSMeans, the productivity rate model was developed by using multiple linear regression (MLR). The use of deterministic MLR in estimating productivity has been successfully utilized by several studies [12-15].

The MLR model is written in the following form:

$y_{i}=\beta_{0}+\beta_{1} x_{i 1}+\beta_{2} x_{i 2}+\ldots+\beta_{p} x_{i p}+\varepsilon_{i}$

where:

$y_{i}$ is the response that corresponds to the levels of explanatory variables $x_{1}, x_{2}, \ldots x_{p}$ at the ith observation

- $\quad \beta_{0}, \beta_{1}, \beta_{2, \ldots} \beta_{p}$ are the coefficients in the linear relationship. For a single factor $(\mathrm{p}=1), \beta_{0}$ is the intercept, and $\beta_{1}$ is the slope of the straight line defined 
$\varepsilon_{1}, \varepsilon_{2}, \ldots, \varepsilon_{n}$ are errors that create scatter around the linear relationship at aeach of the $i=1$ to $\mathrm{n}$ observations. The regression model assumes that these errors are mutually independent, normally distributed, and with a zero mean and variance $\sigma^{2}$. To make estimates of the coefficients in the regression model, the method of least squares is used.

In this paper, MLR is used to determine the statistical relationship between a response (productivity rate) and the explanatory variables in truck activity (capacity, distance, speed, and time). The response variable is expressed in terms of loose cubic yard per hour (lcy/hr) as productivity rate.

The other information about excavator such as rated engine horsepower (HP) and engine model year will be used to estimate the fuel use and emission rates. In order to estimate the fuel use and emission rates, emission factors (EF) and brake-specific fuel consumption (BSFC) were needed. These factors are approximations of amount of fuel consumed and all pollutants emitted by a particular type of equipment during a unit of use. The EF and BSFC for this estimation were based on the calculation algorithm used by the EPA's NONROAD Model [16]. BSFC is reported in pounds per horsepower-hour (lbs/hp$\mathrm{hr}$ ), while EF for pollutants is reported in grams per horsepower-hour (g/hp-hr). These factors used by NONROAD are based on engine dynamometer test data and adjusted accordingly to account for in-use operation that differs from the typical test conditions. For NOx, HC, and $\mathrm{CO}$, the emission factor for a specific type of HDD equipment with a particular model year and age is calculated as follows:

$E F_{a d j(N O x, H C, C O)}=E F_{s s} x T A F x D F$

where:

$\mathrm{EF}_{\mathrm{adj}}$ = final emission factor used in NONROAD, after adjustments for transient operation and deterioration (g/hp-hr)

$\mathrm{EF}_{\mathrm{ss}}=$ zero-hour, steady state emission factor $(\mathrm{g} / \mathrm{hp}-\mathrm{hr})$

$\mathrm{TAF}=$ transient adjustment factor (unit less)

$\mathrm{DF}=$ deterioration factor (unit less)

The zero-hour $\mathrm{EF}_{\mathrm{ss}}$ is a function of the engine's model year and horsepower rating, which defines the engine tier category (Tier $0,1,2,3$, or 4). Transient Adjustment Factors (TAF) are applied to Tier 0 to 3 engines but are not applied to Tier 4 engines because transient emission controls will be a part of all Tier 4 engine design considerations. TAF are calculated as the ration of the transient $\mathrm{EF}$ to the corresponding $\mathrm{EF}_{\mathrm{ss}}$, and maybe greater or less than 1.0. Deterioration Factors (DF) are used to account for increases in emissions over time above a new engines base emission level. This increase might be caused by engine wear, poor maintenance, or modifications. The DF used by NONROAD is based on well-maintained engines and are a linear function based on engine age. The TAF and DF used in the calculations were found in Exhaust and Crankcase Emission Factors for Nonroad Engine Modeling - Compression Ignition [16].

Since PM emissions are dependent on the sulfur content of the fuel consumed by the engine, the calculation for EF of PM is as follows:

$E F_{a d j(P M)}=E F_{s s} \times T A F \times D F-S_{P M a d j}$.

where:

SPMadj = adjustment to PM emission factor for variations in fuel sulfur content (g/hp-hr).

For BSFC or fuel factor, DF is not applied, so the calculation is as follows:

$E F_{\text {adj(BSFC) }}=E F_{s s} x T A F$

NONROAD calculates $\mathrm{CO}_{2}$ emissions directly from inuse BSFC; the carbon that goes into exhaust HC emissions is subtracted for getting the equation for unburned fuel.

$E F_{\text {adj }(\mathrm{CO} 2)}=($ BSFC $\times 453.6-H C) \times 0.87 \times(44 / 12)$

where:

BSFC = in-use adjusted fuel consumption factor (lbs/hphr)

453.6 = conversion from pounds to gram

$\mathrm{HC}=$ in-use adjusted hydrocarbon emission $(\mathrm{g} / \mathrm{hp}-\mathrm{hr})$

$0.87=$ carbon mass fraction of diesel

$44 / 12=$ ratio of $\mathrm{CO}_{2}$ mass to carbon mass

The individual fuel use and emissions values for each item of equipment were calculated according to the methodology presented in Median Life, Annual Activity, and Load Factor Values for Nonroad Engine Emissions Modeling [17].

\section{RESULTS AND DISCUSSION}

The MLR approach was successful in providing model for predicting productivity rate for the excavator activity. Based on the value of R2 $=0.9195$, the MLR equation for predicting productivity accounts approximately $92 \%$ of the variability of the data. With $\alpha=$ 0.05 , all parameters (excluding the intercept) in the model had p-values $<0.0001$ and were statistically significant, except the type of excavator (Table 2). Concerning the types of excavator, since the p-values of type of excavator are bigger than $\alpha=0.05$, it can be concluded that different types of excavation do not significantly lead to different rate of productivity. However, since the type of excavator is categorical variable, it can be used to represent the categories of a qualitative explanatory variable in the regression model. The following models in Table 1 for excavator productivity model were produced: 
TABLE I

Productivity Models For ExCAVATor Activities

\begin{tabular}{|c|c|c|}
\hline $\begin{array}{l}\text { Excavator } \\
\text { Type }\end{array}$ & Soil Type & Productivity Model \\
\hline \multirow[t]{4}{*}{ Excavator } & Sand-gravel & $\begin{array}{l}Y=-3.95+3.32+8.47- \\
2.07 X_{1}+55.13 X_{2}\end{array}$ \\
\hline & $\begin{array}{l}\text { Sandy clay- } \\
\text { loam }\end{array}$ & $\begin{array}{l}Y=-3.95+3.32+14.91- \\
2.07 X_{1}+55.13 X_{2}\end{array}$ \\
\hline & Common earth & $\begin{array}{l}Y=-3.95+3.32+16.41- \\
2.07 X_{1}+55.13 X_{2}\end{array}$ \\
\hline & Clay & $\begin{array}{l}Y=-3.95+3.32-2.07 X_{I} \\
+55.13 X_{2}\end{array}$ \\
\hline \multirow[t]{4}{*}{$\begin{array}{l}\text { Excavator- } \\
\text { truck mounted }\end{array}$} & Sand-gravel & $\begin{array}{l}Y=-3.95+4.17+8.47- \\
2.07 X_{1}+55.13 X_{2}\end{array}$ \\
\hline & $\begin{array}{l}\text { Sandy clay- } \\
\text { loam }\end{array}$ & $\begin{array}{l}Y=-3.95+4.17+14.91- \\
2.07 X_{1}+55.13 X_{2}\end{array}$ \\
\hline & Common earth & $\begin{array}{l}Y=-3.95+4.17+16.41- \\
2.07 X_{1}+55.13 X_{2}\end{array}$ \\
\hline & Clay & $\begin{array}{l}Y=-3.95+4.17-2.07 X_{1} \\
+55.13 X_{2}\end{array}$ \\
\hline \multirow[t]{4}{*}{$\begin{array}{l}\text { Excavator- } \\
\text { trench box }\end{array}$} & Sand-gravel & $\begin{array}{l}Y=-3.95+8.47-2.07 X_{1} \\
+55.13 X_{2}\end{array}$ \\
\hline & $\begin{array}{l}\text { Sandy clay- } \\
\text { loam }\end{array}$ & $\begin{array}{l}Y=-3.95+14.91-2.07 X_{1} \\
+55.13 X_{2}\end{array}$ \\
\hline & Common earth & $\begin{array}{l}Y=-3.95+16.41-2.07 X_{1} \\
+55.13 X_{2}\end{array}$ \\
\hline & Clay & $Y=-3.95-2.07 X_{1}+55.13 X_{2}$ \\
\hline
\end{tabular}

where:

$\mathrm{Y}=$ productivity rate $(\mathrm{lcy} / \mathrm{hr})$

$\mathrm{X}_{1}=$ trench depth (feet)

$\mathrm{X}_{2}=$ bucket size (lcy)

TABLE II

Multiple LineAR REGRESSION ANALySIS RESUltS

\begin{tabular}{l|c|r|r|r}
\multicolumn{5}{c}{ MULTIPLE LINEAR REGRESSION ANALYSIS RESULTS } \\
\hline Variable & Coefficient & $\begin{array}{c}\text { Parameter } \\
\text { estimate }\end{array}$ & t-value & p-value \\
\hline Intercept & $\beta_{0}$ & -3.946 & -0.91 & 0.3656 \\
\hline $\begin{array}{l}\text { Soil type } \\
1\end{array}$ & $\beta_{1}$ & 8.465 & 2.36 & 0.0193 \\
\hline $\begin{array}{l}\text { Soil type } \\
2\end{array}$ & $\beta_{2}$ & 14.907 & 4.16 & $<0.0001$ \\
\hline $\begin{array}{l}\text { Soil type } \\
3\end{array}$ & $\beta_{3}$ & 16.412 & 4.58 & $<0.0001$ \\
\hline Depth & $\beta_{4}$ & -2.069 & -9.92 & $<0.0001$ \\
\hline $\begin{array}{l}\text { Bucket } \\
\text { Size }\end{array}$ & $\beta_{5}$ & 55.131 & 42.19 & $<0.0001$ \\
\hline $\begin{array}{l}\text { Excavator } \\
\text { type 1 }\end{array}$ & $\beta_{6}$ & 3.317 & 1.39 & 0.1676 \\
\hline $\begin{array}{l}\text { Excavator } \\
\text { type 2 }\end{array}$ & $\beta_{7}$ & 4.166 & 0.72 & 0.4743 \\
\hline
\end{tabular}

The predictors or explanatory variables included in the model were selected by using two methods: Mallow's C(p) values and Stepwise Selection method. In Table 3, with $\mathrm{C}(\mathrm{p})$ value of 4.297 and $\mathrm{R}$-square of 0.9194 , soil type, trench depth, bucket size and type of excavator can be included in the model. In stepwise selection method, bucket size, trench depth, and soil type were included in the model, and gave the R-square value of 0.9185 (Table 4). From these two methods, the final regression model for productivity can include bucket size, trench depth, soil type, and type of excavator.
TABLE III

Summary of Four Bests of Mallow's C(P) Model Selection Results

\begin{tabular}{c|c|l}
\hline $\mathbf{C}(\mathbf{p})$ & R-square & Predictors \\
\hline 4.297 & 0.9194 & $\begin{array}{l}\text { Soil type 1,4; depth; bucket size, } \\
\text { excav type 3 }\end{array}$ \\
\hline 4.309 & 0.9185 & Soil type 1,4; depth, bucket size \\
\hline 4.788 & 0.9192 & $\begin{array}{l}\text { Soil type 1,4; depth, bucket size, } \\
\text { excav type 1 }\end{array}$ \\
\hline 6.023 & 0.9195 & $\begin{array}{l}\text { Soil type 1,3; depth, bucket size, } \\
\text { excav type 3 }\end{array}$ \\
\hline
\end{tabular}

TABLE IV

SuMmary of StePWISE SELECTION RESUlts

\begin{tabular}{l|c|c|c|c}
\hline Step & $\begin{array}{c}\text { Variable } \\
\text { entered }\end{array}$ & Model R & F-value & P-value \\
\hline 1 & Bucket size & 0.8654 & 1240.52 & $<0.0001$ \\
\hline 2 & Depth & 0.9083 & 89.85 & $<0.0001$ \\
\hline 3 & Soil type 4* & 0.9149 & 14.87 & $<0.0001$ \\
\hline 4 & Soil type 1* & 0.9185 & 8.38 & 0.0042 \\
\hline
\end{tabular}

The next step in the model building is the validation of the selected model. The validation is set to evaluate the reasonableness and predictive ability of the selected model. The productivity model in this paper is validated by using two methods: a plot showing comparison of predicted and actual data, and data splitting method. Figure 2 showing the predicted versus the actual results for the productivity model was made. The predicted results are those that were generated by the model and the actual are those that were taken from the RSMeans data. Ideally, a plot of the predicted versus the actual results will produce a line with a slope of 1.0 (accuracy), $\mathrm{R}^{2}=1.0$ (precision), and intercept $=0$ (bias). The plot from the model shows the slope of $0.9195, \mathrm{R}^{2}=0.9195$, and intercept $=6.26 \mathrm{lcy} / \mathrm{hr}$, thus, the model was considered to be accurate, precise, and had no bias.

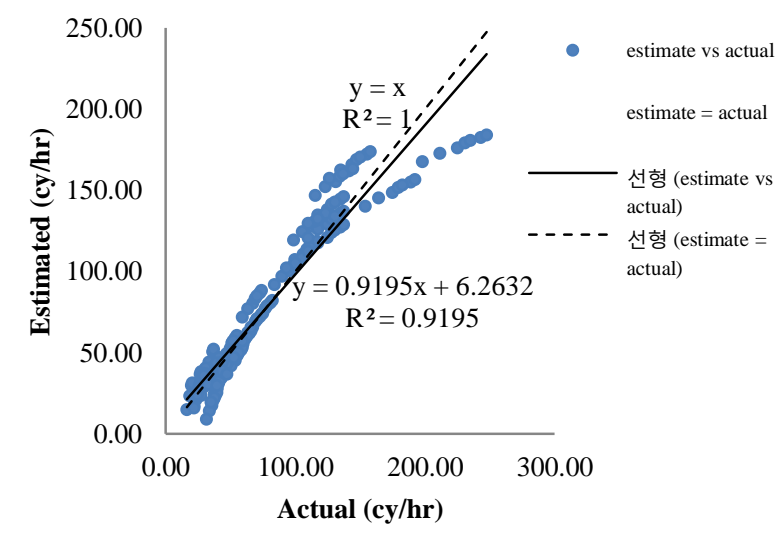

FIGURE II

The Plot of Predicted Versus Actual Productivity Rate for EXCAVATOR

Because the data set is large $(n=195)$, the model was also validated by using cross-validation procedure or data splitting. The data set were equally split for modelbuilding or training sample, and validation or prediction 
set. The purpose of this cross-validation procedure is to assess the adequacy of the model on an independent data set. A means of measuring the actual predictive capability of the regression model is to use this model to predict each case in the validation data set and then to calculate the mean of the squared prediction errors, to be denoted by MSPR (mean squared prediction error). The calculation of MSPR is as follows:

$\operatorname{MSPR}=\frac{\sum_{i=1}^{n}\left(Y i-\widehat{Y}^{2}\right.}{n}$

The MSPR from the productivity model is 214.5 and fairly close to the MSE based on the regression fit to the model-building data set of 225.52. The MSE for the regression model of productivity rate used here is not seriously biased and gives an appropriate indication of the predictive ability of the model.

The overall calculation formula for obtaining the total fuel use and emissions estimates are formed by combining the productivity rate model with calculation algorithm of the NONROAD model. In order to estimate the total emissions and fuel use from a certain quantity of soil excavated by an excavator, the total duration of activity is needed. In equations 7-9 the total duration in hours (hr) can be obtained by dividing the total soil quantity with the productivity rate in loose-cubic yard per hour (lcy/hr). Once the total duration obtained and engine HP is known, the total emission in grams (gr) and total fuel use (gal) can be calculated by multiplying the EF (g/hp-hr) or BSFC (gal/hp-hr) from NONROAD with horsepower (hp) and duration (hr) (Eqs. 10-13).

$\mathrm{E}(\mathrm{gr})=$ Duration $(\mathrm{hr}) *$ engine horsepower $(\mathrm{hp}) *$ Emission factor $\left(\frac{\mathrm{gr}}{\mathrm{hp} . \mathrm{hr}}\right)$

$\mathrm{E}(\mathrm{gr})=\frac{\text { Soil Quantity }(\mathrm{cy})}{\text { Productivity Rate }\left(\frac{\mathrm{cy}}{\mathrm{hr}}\right)} *$ engine horsepower $(\mathrm{hp}) *$ Emission factor $\left(\frac{\mathrm{gr}}{\mathrm{hp} . \mathrm{hr}}\right)$

$\mathrm{F}(\mathrm{gal})=\frac{\text { Soil Quantity }(\mathrm{cy})}{\text { Productivity Rate }\left(\frac{\mathrm{cy}}{\mathrm{hr}}\right)} *$ engine horsepower $(\mathrm{hp}) * \mathrm{BSFC}\left(\frac{\mathrm{gal}}{\mathrm{hp.hr}}\right)$

The formula for estimating each pollutants emission and fuel use are as follows:

For $\mathrm{HC}, \mathrm{CO}$, and $\mathrm{NOx}$ :

$\mathrm{E}=\frac{\mathrm{Q}}{(-3.9467+\mathrm{fs}-2.069 \mathrm{~d}+55.13 \mathrm{~B}+\mathrm{ft})} * \mathrm{HP}^{*} \mathrm{EFss}^{*} \mathrm{TAF}^{*} \mathrm{DF}$

For PM:

$\mathrm{E}=\frac{\mathrm{Q}}{(-3.9467+\mathrm{fs}-2.069 \mathrm{~d}+55.13 \mathrm{~B}+\mathrm{ft})} * \mathrm{HP}^{*}\left(\left(\mathrm{EFss}^{*} \mathrm{TAF} * \mathrm{DF}\right)-\mathrm{S}_{\mathrm{PM}}\right)$

For $\mathrm{CO}_{2}$ :

$\mathrm{E}=\frac{\mathrm{Q}}{(-3.9467+\mathrm{fs}-2.069 \mathrm{~d}+55.13 \mathrm{~B}+\mathrm{ft})} * \mathrm{HP}^{*}\left(\left(\mathrm{BSFC}^{*} 453.6-\mathrm{HC}\right) * 0.87 *\left(\frac{44}{12}\right)\right)$

For Fuel Use:

$\mathrm{F}=\frac{\mathrm{Q}}{(-3.9467+\mathrm{fs}-2.069 \mathrm{~d}+55.13 \mathrm{~B}+\mathrm{ft})} * \mathrm{HP} *(\mathrm{BSFC}) * \mathrm{TAF}$

where,

$\mathrm{E}=$ emission $(\mathrm{gr})$

$\mathrm{F}=$ fuel use (gal)
$\mathrm{Q}=$ quantity of soil dozed/moved (cy)

$f s=$ soil type factor (common earth: 8.47 ; sandy clay-

loam: 14.91; sand-gravel: 16.41; clay: 0)

$f t=$ excavator type factor (excavator: 3.32 ; excav-truck

mounted: 4.17; excav-trench box: 0 )

$\mathrm{HP}=$ engine horsepower $(\mathrm{hp})$

EFss = steady state emission factor (gr/hp.hr)

$\mathrm{TAF}=$ transient adjustment factor (unit less)

$\mathrm{DF}=$ deterioration factor (unit less)

$\mathrm{S}_{\mathrm{PM}}=$ fuel sulfur content for PM (gr/hp.hr)

$\mathrm{EF}(\mathrm{BSFC})=$ emission factor for brake-specific-fuelconsumption (gal/hp.hr)

For practicability and in order to make this estimating tool more user-friendly, a spread sheet-based user interface was developed. The interface was made by using Visual Basic (VBA) program for Microsoft Excel. The site manager, HDD equipment operator, or construction estimator can use the interface by filling out the activity input performed by the equipment in the dialog box. The information needed to run or start the estimation are engine size, engine model year, type of excavator, type of soil, bucket size, trench depth, trench length, and trench width. The appearance of the interface for truck activity is shown in Figure 3.

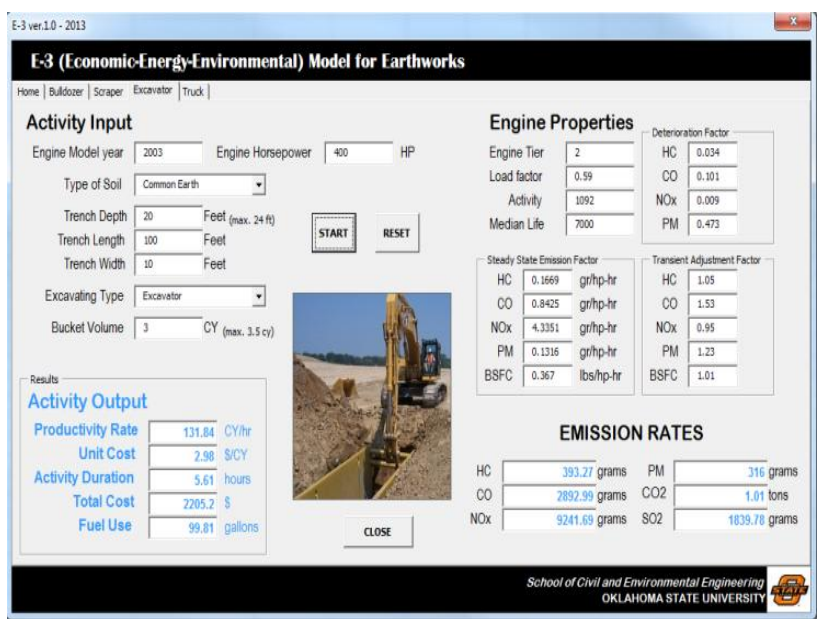

FIGURE III

USER'S INTERFACE OF FUEL USE AND EMISSION ESTIMATING TOOL

To demonstrate the methodology for excavator activity, an example is presented that has inputs of a 2003-model year - 400 HP excavator, with bucket capacity of $3 \mathrm{lcy}$. The excavator has to dig 100 feet long 10 feet wide -20 feet deep of trench in common earth type of soil with regular type of excavator. As the user click the 'start' button on the interface, the results will appear as shown in Figure 4. The engine size and model year will determine the engine tier, steady-state emission factor (EFss), load factor (LF), median life, deterioration factor (DF), and transient adjustment factor (TAF). While the rest of excavator activity input variables will be used for determining productivity rate. This example of 
excavator activity resulted in the fuel use estimation of 99.81 gallons, $\mathrm{HC}$ emission of 393 grams, $\mathrm{CO}$ emissions of 2,893 grams, NOx emission of 9,242 grams, PM emission of 316 grams, and $\mathrm{CO}_{2}$ emission of 1.01 tons.

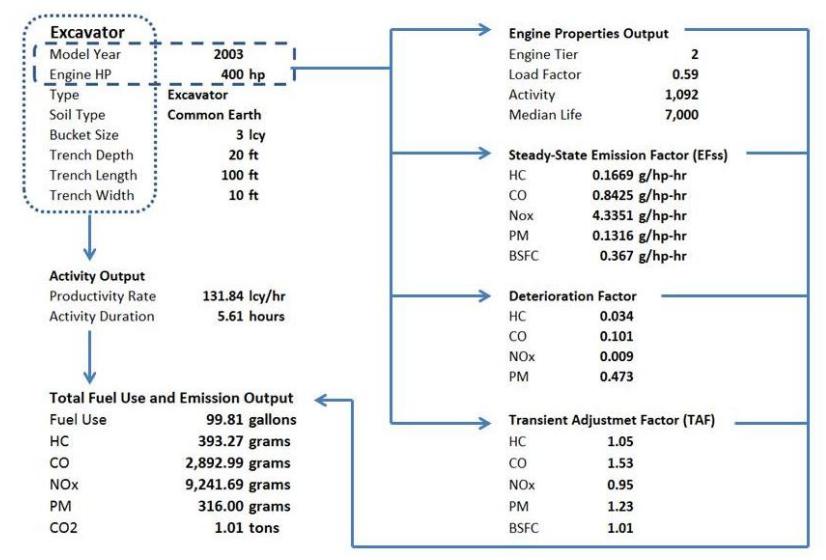

FIGURE IV

Calculation Algorithm of Fuel Use and Emission Estimating Tool

The estimation results obtained from this proposed tool can also be used for conducting sensitivity analysis. Results for six different trench depth $(2.5,5,8,12,17$, and 22 feet), trench length of 100 feet, trench width of 10 feet, performed by regular excavator with 3 lcy bucket capacity, are presented in Table 5 to show the sensitivity to changes in activity conditions.
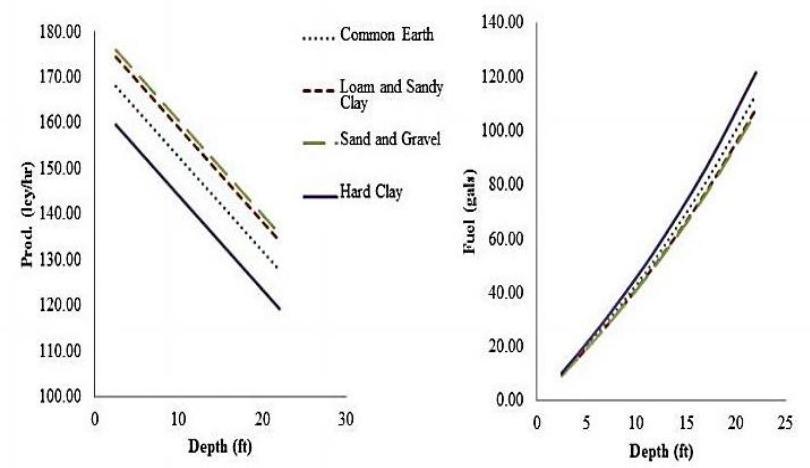

FIGURE V

Relationship Between Excavator Productivity Rate and Fuel Use WITH ITS TRENCH DEPTH

Based on the information on Figure 5, there is an inverse linear relationship between productivity rate and the trench depth, and positive relationship between fuel use and trench depth. The productivity rate decreases when the excavator has to dig deeper trench. Furthermore, for a specific soil type, clay gives the lowest productivity rate, while as the highest, sand-gravel and sandy clayloam lead to relatively same productivity rate.
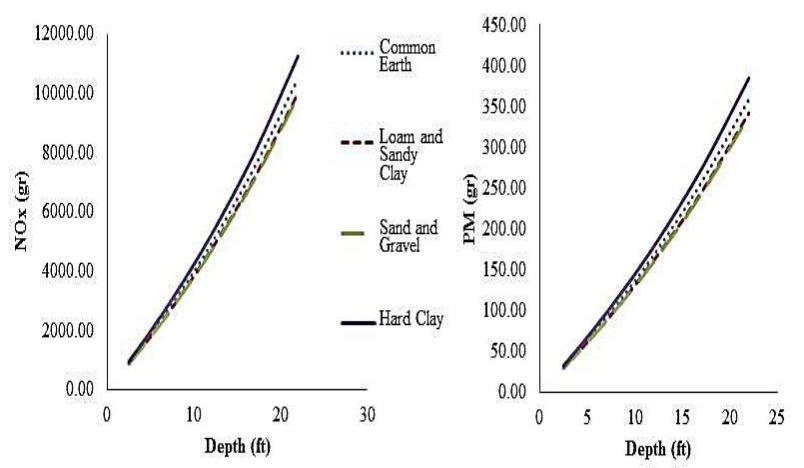

FIGURE VI

Relationship BetweEn PM AND NOx EMISSIONS With TRENCH DEPTH

Figure 5 also displayed the fuel use for the $400 \mathrm{hp}$ excavator with respect to the trench depth. This is a positive relationship in that the fuel use increases as the trench goes deeper. This positive relationship is also shown between all pollutant gases and the trench depth. It can be understood that since deeper trench led to lower productivity, the duration needed to perform the activity become longer (Table 5), and the fuel use become higher. Fuel use factor (using BSFC) and emission factor (EF) for all pollutants are highly correlated, since both uses the engine size (hp) and activity duration (hr) as the multipliers to obtain total amount of fuel and emission in gallons and grams. It is shown on Figure 6 that the shapes of the curves are the same for both parameters. Similarly to the fuel use for this excavator, using two most important pollutants of HDD; PM and NOx, deeper trench will have higher total amount of emission.
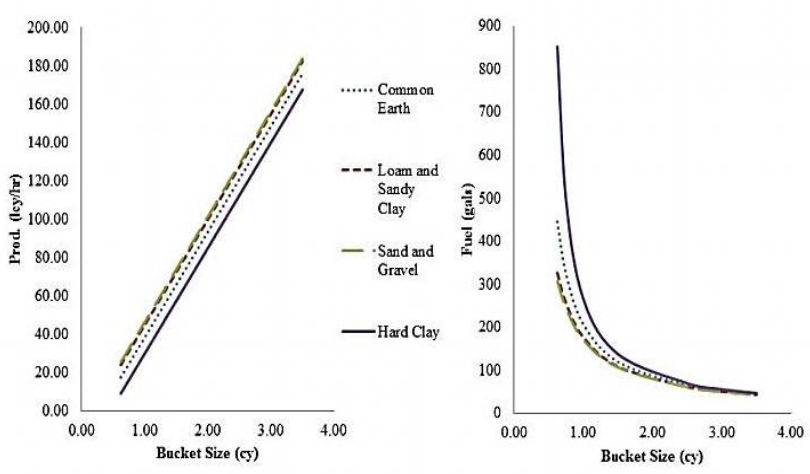

FIGURE VII

Relationship Between Truck Productivity Rate and Fuel Use with CyCle Distance

Another example demonstrating the sensitivity analysis for excavator activity is using the same engine size and model year with fixed size of trench $(100 \mathrm{ft}$ length, $10 \mathrm{ft}$ width, and $12 \mathrm{ft}$ depth). The excavator has to perform this activity by using various sizes of bucket $(0.75,1,1.5,2.5,3$, and $3.5 \mathrm{cy})$. Based on the information on Table 6 and Figure 7, there is a positive relationship between productivity rate and the bucket size. The productivity rate increases as the bucket size increases. Furthermore, for a specific type of soil, there is no big difference of productivity rate shown by all type of soil, 
however clay consistently has the lowest estimated productivity. Figure 7 also displayed the fuel use for the $400 \mathrm{hp}$ excavator with respect to its bucket capacity. This is an inverse relationship in that the fuel use decreases as the excavator's bucket size increases.

\begin{tabular}{|c|c|c|c|c|c|c|c|c|c|}
\hline Type of Soil & $\begin{array}{l}\text { Depth } \\
\text { (ft) }\end{array}$ & $\begin{array}{l}\text { Productivity } \\
\text { (cy/hr) }\end{array}$ & $\begin{array}{l}\text { Duration } \\
\text { (hir) }\end{array}$ & $\begin{array}{l}\text { fuel } \\
\text { (gals) }\end{array}$ & He (go) & $\operatorname{Co}(\mathrm{gr})$ & NOX (BI) & PM (gr) & $\mathrm{CO} 2$ (tons) \\
\hline Common Earth & 2.5 & 168.05 & 0.55 & 9.79 & 38.56 & 283.63 & 906.05 & 30.98 & 0.09 \\
\hline Loam and Sandy Clay & 2.5 & 174.50 & 0.53 & 9.43 & 37.15 & 273.31 & 873.10 & 29.85 & 0.09 \\
\hline Sand and Gravel & 2.5 & 176.00 & 0.53 & 9.43 & 37.15 & 273.31 & 873.10 & 29.85 & 0.09 \\
\hline Dense Hard Clay & 2.5 & 159.59 & 0.58 & 10.32 & 40.66 & 299.10 & 955.47 & 32.67 & 0.09 \\
\hline Common Earth & 5 & 162.88 & 1.14 & 20.28 & 79.92 & 587.88 & 1877.99 & 64.21 & 0.19 \\
\hline Loam and Sandy Clay & 5 & 169.32 & 1.09 & 19.39 & 76.41 & 562.10 & 1795.62 & 61.40 & 0.18 \\
\hline Sand and Gravel & 5 & 170.83 & 1.08 & 19.22 & 75.71 & 556.94 & 1779.15 & 60.83 & 0.18 \\
\hline Dense Hard Clay & 5 & 154.42 & 1.20 & 21.35 & 84.12 & 618.82 & 1976.83 & 67.59 & 0.19 \\
\hline Common Earth & 8 & 156.67 & 1.89 & 33.63 & 132.49 & 974.64 & 3113.51 & 106.46 & 0.31 \\
\hline Loam and Sandy Clay & 8 & 163.11 & 1.81 & 32.20 & 126.88 & 933.39 & 2981.72 & 101.95 & 0.29 \\
\hline Sand and Gravel & 8 & 164.62 & 1.80 & 32.03 & 126.18 & 928.23 & 2965.25 & 101.39 & 0.29 \\
\hline Dense Hard Clay & 8 & 148.21 & 2.00 & 35.58 & 140.20 & 1031.37 & 3294.72 & 112.66 & 0.32 \\
\hline Common Earth & 12 & 148.40 & 2.99 & 53.20 & 209.60 & 1541.90 & 4925.60 & 168.42 & 0.49 \\
\hline Loam and Sandy Clay & 12 & 154.84 & 2.87 & 51.06 & 201.19 & 1480.01 & 4727.92 & 161.66 & 0.47 \\
\hline Sand and Gravel & 12 & 156.34 & 2.84 & 50.53 & 199.09 & 1464.54 & 4678.50 & 159.97 & 0.46 \\
\hline Dense Hard Clay & 12 & 139.93 & 3.17 & 56.40 & 222.22 & 1634.72 & 5222.13 & 178.56 & 0.51 \\
\hline Common Earth & 17 & 138.05 & 4.56 & 81.13 & 319.66 & 2351.52 & 7511.96 & 256.86 & 0.74 \\
\hline Loam and Sandy Clay & 17 & 144.49 & 4.35 & 77.40 & 304.94 & 2243.23 & 7166.01 & 245.03 & 0.71 \\
\hline Sand and Gravel & 17 & 146.00 & 4.31 & 76.68 & 302.14 & 2222.60 & 7100.12 & 242.77 & 0.70 \\
\hline Dense Hard Clay & 17 & 129.58 & 4.85 & 86.29 & 339.99 & 2501.07 & 7989.69 & 273.19 & 0.79 \\
\hline Common Earth & 22 & 127.70 & 6.37 & 113.34 & 446.55 & 3284.91 & 10493.68 & 358.81 & 1.03 \\
\hline Loam and Sandy Clay & 22 & 134.14 & 6.07 & 108.00 & 425.52 & 3130.20 & 9999.47 & 341.91 & 0.99 \\
\hline Sand and Gravel & 22 & 135.65 & 6.00 & 106.75 & 420.61 & 3094.11 & 9884.16 & 337.97 & 0.97 \\
\hline Dense Hard Clay & 22 & 119.24 & 6.83 & 121.52 & 478.79 & 3522.12 & 11251.46 & 384.72 & 1.11 \\
\hline
\end{tabular}

Activity Estimates for Trench With Length of 100 FEet, Trench Width of 10 FEet, Performed by RegulaR EXCAVATOR WITH 3 LCY BUCKET CAPACITY.

\begin{tabular}{|c|c|c|c|c|c|c|c|c|c|}
\hline Type of Soil & $\begin{array}{l}\text { Bucket } \\
\text { Vol. } \\
\text { (c)l }\end{array}$ & $\begin{array}{l}\text { Productivity } \\
\text { [cy/hi] }\end{array}$ & $\begin{array}{l}\text { Duration } \\
\text { (hir) }\end{array}$ & $\begin{array}{l}\text { fuel } \\
\text { (gals) }\end{array}$ & $\mathrm{HC}(\mathrm{gC})$ & $\mathrm{CO}(\mathrm{gr})$ & Nox (gr) & PM (gr) & $\begin{array}{c}\mathrm{CO}_{2} \\
\text { (tons) }\end{array}$ \\
\hline Common Earth & 0.75 & 24.35 & 18.23 & 324.35 & 1277.95 & 9400.93 & 30031.36 & 1026.86 & 2.96 \\
\hline Loam and Sandy Clay & 0.75 & 30.79 & 14.42 & 256.56 & 1010.86 & 7436.17 & 23754.92 & 812.25 & 2.34 \\
\hline Sand and Gravel & 0.75 & 32.30 & 13.75 & 244.64 & 963.89 & 7090.66 & 22651.19 & 774.51 & 2.23 \\
\hline Dense Hard Clay & 0.75 & 15.89 & 27.94 & 497.11 & 1958.63 & 14408.22 & 46027.22 & 1573.81 & 4.54 \\
\hline Common Earth & 1.00 & 38.13 & 11.64 & 207.1 & 815.98 & 6002.57 & 19175.26 & 655.66 & 1.89 \\
\hline Loam and Sandy Clay & 1.00 & 44.58 & 9.96 & 177.21 & 698.21 & 5136.22 & 16407.70 & 561.03 & 1.62 \\
\hline Sand and Gravel & 1.00 & 46.08 & 9.64 & 171.52 & 675.78 & 4971.20 & 15880.54 & 543.00 & 1.57 \\
\hline Dense Hard Clay & 1.00 & 29.67 & 14.96 & 266.17 & 1048.72 & 7714.64 & 24644.49 & 842.67 & 2.43 \\
\hline Common Earth & 1.50 & 65.70 & 6.76 & 120.28 & 473.89 & 3486.03 & 11136.15 & 380.78 & 1.10 \\
\hline Loam and Sandy Clay & 1.50 & 72.14 & 6.15 & 109.42 & 431.12 & 3171.46 & 10131.26 & 346.42 & 1.00 \\
\hline Sand and Gravel & 1.50 & 73.65 & 6.03 & 107.29 & 422.71 & 3109.58 & 9933.58 & 339.66 & 0.98 \\
\hline Dense Hard Clay & 1.50 & 57.23 & 7.76 & 138.07 & 543.99 & 4001.71 & 12783.51 & 437.11 & 1.26 \\
\hline Common Earth & 2.50 & 120.83 & 3.67 & 65.3 & 257.27 & 1892.56 & 6045.81 & 206.72 & 0.60 \\
\hline Loam and Sandy Clay & 2.50 & 127.27 & 3.49 & 62.09 & 244.65 & 1799.74 & 5749.28 & 196.59 & 0.57 \\
\hline Sand and Gravel & 2.50 & 128.78 & 3.45 & 61.38 & 241.85 & 1779.11 & 5683.39 & 194.33 & 0.56 \\
\hline Dense Hard Clay & 2.50 & 112.37 & 3.95 & 70.28 & 276.90 & 2036.95 & 6507.07 & 222.50 & 0.64 \\
\hline Common Earth & 3.00 & 148.40 & 2.99 & 53.2 & 209.60 & 1541.90 & 4925.60 & 168.42 & 0.49 \\
\hline Loam and Sandy Clay & 3.00 & 154.84 & 2.87 & 51.06 & 201.19 & 1480.01 & 4727.92 & 161.66 & 0.47 \\
\hline Sand and Gravel & 3.00 & 156.34 & 2.84 & 50.53 & 199.09 & 1464.54 & 4678.50 & 159.97 & 0.46 \\
\hline Dense Hard Clay & 3.00 & 139.93 & 3.17 & 56.4 & 222.22 & 1634.72 & 5222.13 & 178.56 & 0.51 \\
\hline Common Earth & 3.50 & 175.96 & 2.52 & 44.84 & 176.66 & 1299.52 & 4151.35 & 141.95 & 0.41 \\
\hline Loam and Sandy Clay & 3.50 & 182.40 & 2.43 & 43.23 & 170.35 & 1253.11 & 4003.08 & 136.88 & 0.39 \\
\hline Sand and Gravel & 3.50 & 183.91 & 2.41 & 42.88 & 168.94 & 1242.80 & 3970.14 & 135.75 & 0.39 \\
\hline Dense Hard Clay & 3.50 & 167.50 & 2.65 & 47.15 & 185.77 & 1366.56 & 4365.50 & 149.27 & 0.43 \\
\hline
\end{tabular}

FIGURE IX

ACtivity Estimates For TRENCH With LENGTH OF 100 FEET, TRENCH WIDTH OF 10 FEET,

Performed by Regular EXCAVATOR With Various Bucket CAPACITY

Because the bigger bucket size distance led to higher productivity, the duration needed to perform the activity become shorter (Table 6), and the fuel use become lower. Specifically for clay, using bucket size less than 1 cy makes the excavator consumes a large amount of fuel. This consumption rate then decreases dramatically when the excavator uses bucket size of 1 cy or more. It starts decreasing gradually with declined slope when using bigger bucket size. As for the excavator using 3 or more cubic yard bucket, the fuel consumed for excavating all type of soil are relatively the same. It can be used as recommendation for fleet operator or HDD equipment operator, that for any type of soil, using excavator wibucket size of $3 \mathrm{cy}$ or more will lead to more efficient fuel use.

\section{CONCLUSION AND RECOMMENDATION}

This paper presented a methodology and tool for estimating the fuel use and emissions for a common earthwork activity performed by an excavator. The MLR approach proved to be a useful alternative for estimating productivity rate for the excavator. The MLR model for the productivity rate can explain $92 \%$ of the variability in the data. Since the model is proven accurate and precise, it 
is good to be used as a benchmark for estimating the fuel use and emissions from a certain type of HDD equipment performing earthwork activities. The productivity rate from this model (lcy/hr) is used with published fuel use rate (gal/hp-hr) and emission factors (g/hp-hr) from EPA's NONROAD model to estimate the total fuel use and total emissions of $\mathrm{NO}_{\mathrm{x}}, \mathrm{PM}, \mathrm{HC}, \mathrm{CO}$, and $\mathrm{CO}_{2}$ from excavator.

Based on the methodology presented in this paper, the results revealed several trends related to fuel use and emissions of the excavator. For example, the fuel use and all pollutants emissions increase as the trench depth increase, because digging deeper trench leads to lower productivity. Meanwhile, as the excavator's bucket size increase, the fuel use and all pollutants emissions decrease, because the productivity gets higher when the excavator uses bigger bucket size.

After the estimating tool has been developed, it is recommended for future research to validate and calibrate the model by real-world fuel use and emissions data collected from HDD equipment. This will be done by using a portable emissions measurement system (PEMS) that is able to record second-by-second fuel use, emissions, and engine data from the HDD performing earthwork activities. The field data collection and analysis process will permit evaluation of the variability in fuel use and emissions rates among equipment based on type, engine size, engine load, and usage.

The estimating tool proposed in this paper will be an effective means for assessing the energy and environmental impacts of construction activities and will allow equipment owners or fleet managers, policy makers, and project stakeholders to evaluate more sustainable alternatives. The tool will help the contractor to estimate the fuel quantities that will be required and the total expected pollutant emissions for the project, which would be valuable information for a preliminary environmental assessment of the project.

\section{REFERENCES}

[1] H.-W. Choi, "Measurement and modeling of the activity, energy, and emissions of conventional and alternative vehicles", Doctor of Philosophy Dissertation, North Carolina State University, Raleigh, NC, 2009.

[2] P. Lewis, "Estimating fuel use and emission rates of nonroad diesel construction equipment performing representative duty cycles", Doctor of Philosophy Dissertation, North Carolina State University, Raleigh, NC, 2009.

[3] W. Rasdorf, C. Frey, P. Lewis, K. Kim, S.-H. Pang, S. Abolhassani, "Field procedures for real-world measurements of emissions from diesel construction vehicles", Journal of Infrastructure Systems, vol. 16, no. 3, pp. 216-225, 2010.

[4] P. Lewis, H.C. Frey, W. Rasdorf, "Development and Use of Emissions Inventories for Construction Vehicles", Transportation Research Record: Journal of the Transportation Research Board, vol. 2123 , no. 6 , pp. 46-53, 2009.

[5] H.C. Frey, K. Kim, "Comparison of Real-World Fuel Use and Emissions for Dump Trucks Fueled with B20 Biodiesel Versus Petroleum Diesel", Transportation Research Record: Journal of the Transportation Research Board, vol. 1987, pp. 110-117, 2007.
[6] C. Ahn, W. Pan, S. Lee, F. Pena-Mora, "Enhanced estimation of air emissions from construction operations based on discrete event simulation", in the International Conference on Computing in Civil and Building Engineering, Nottingham, UK, 2010.

[7] W. Pan, "The Application of Simulation Methodologies on Estimating Gas Emissions from Construction Equipment", Master of Science Thesis, University of Alberta, Edmonton, Alberta, 2011.

[8] H.-x. Li, Z. Lei, "Implementation of Discrete-Event Simulation (DES) in Estimating and Analyzing $\mathrm{CO}_{2}$ Emission During Earthwork of Building Construction Engineering", in the 17th International Conference on Industrial Engineering and Engineering Management (IEEM), Xiamen, China, 2010.

[9] A.H. Ammouri, I. Srour, R.F. Hamade, "Carbon Footprint Calculator for Construction Projects (CFCCP)", in the Advances in Sustainable Manufacturing - 8th Global Conference on Sustainable Manufacturing, Berlin-Heidelberg, Germany, 2011.

[10] G.J. Thompson, C.M. Atkinson, N.N. Clark, T.W. Long, E. Hanzevack, "Neural network modelling of the emissions and performance of a heavy duty diesel engine", Journal of Automobile Engineering, vol. 214, no. 2, pp. 111-126, 2000.

[11] D. Karonis, E. Lois, F. Zannikos, A. Alexandridis, H. Sarimveis, "A Neural Network Approach for the Correlation of Exhaust Emissions from a Diesel Engine with Diesel Fuel Properties". Energy \& Fuels, vol. 17, no. 5, pp. 1259-1265, 2003.

[12] A.O. Akinsola, "An intelligent model of variations contingency on construction projects", Doctor of Philosophy Dissertation, University of Wolverhampton, Wolverhampton, 1997.

[13] A. Akintoye, M. Skitmore, "Models of UK private sectors quarterly construction demand", Construction Management and Economics, vol. 12, no. 1, pp. 3-13, 1994.

[14] D.J. Edwards, G.D. Holt, F.C. Harris, “A comparative analysis between the multilayer perceptron 'neural network' and multiple regression analysis for predicting construction plant maintenance cost”, Journal of Quality in Maintenance Engineering, vol. 6, no. 1, pp. 45-60, 2000.

[15] S.D. Smith, "Earthmoving Productivity Estimation Using Linear Regression Techniques", Journal of Construction Engineering and Management, vol. 125, no. 3, pp. 133-141, 1999.

[16] EPA. "Exhaust and Crankcase Emission Factors for Nonroad Engine Modeling - Compression Ignition", Washington D.C.: Office of Transportation and Air Quality, 2010a.

[17] EPA. "Median Life, Annual Activity, and Load Factor Values for Nonroad Engine Emissions Modeling”, Washington D.C.: Office of Transportation and Air Quality, 2010b. 